\title{
Gastroprotective activity of the hydroethanolic extract and ethyl acetate fraction from Kalanchoe pinnata (Lam.) Pers.
}

\author{
Flávia Sobreira', Leandro Santoro Hernandes ${ }^{1}$, Alberto Vetore-Neto¹, Ingrit E. Collantes Díaz², \\ Fernanda Carvalho de Santana ${ }^{3}$, Jorge Mancini-Filho ${ }^{3}$, Elfriede Marianne Bacchi ${ }^{1, *}$
}

\begin{abstract}
${ }^{1}$ Department of Pharmacy, Faculty of Pharmaceutical Sciences, University of São Paulo, SP, Brazil, ${ }^{2}$ Center for Research in Biodiversity, Botany Laboratory and Herbarium UNIP and Extraction Laboratory, Paulista University, São Paulo, Brazil, ${ }^{3}$ Department of Food Science and Experimental Nutrition, University of São Paulo, SP, Brazil
\end{abstract}

\begin{abstract}
Peptic ulcers are an important pathology, and the search for safer and more effective treatment methods is of paramount importance. In this study, we assess the gastroprotective effects of the hydroethanolic extract (HE) and ethyl acetate fraction (EAF) from Kalanchoe pinnata leaves against an ethanol/HCl-induced ulcer model in rats. The HE reduced gastric lesions by approximately $47 \%$ ( $400 \mathrm{mg} / \mathrm{kg})$. A significant inhibition of the gastric lesions by $50 \%$ was observed after pretreatment with the EAF ( $200 \mathrm{mg} / \mathrm{kg})$. Quercetrin and quercetin 3-O- $\alpha$-L-arabinopyranosyl-( $1 \rightarrow 2)-\alpha$-L-rhamnopyranoside were isolated and identified in the flavonoid fraction (EAF) by HPLC and NMR analyses because this fraction showed the highest gastroprotective effect. This fraction demonstrated high antioxidant activities $\left(\mathrm{CE}_{50}=41.91\right.$ $\mu \mathrm{g} / \mathrm{mL}$ ) by DPPH in comparison with Trolox $^{\circledR}$ and 11.33 mmol Trolox $^{\circledR}$ equivalent by ORAC. In conclusion, the HE and FAE from $K$. pinnata displayed gastroprotective activity in rats, most likely due to the presence of flavonoids.
\end{abstract}

Uniterms: Gastric ulcer/study/rats. Gastric ulcer/treatment. Kalanchoe pinnata/chromatographic profile. Kalanchoe pinnata/gastroprotective activity. Quercetrin. Quercetin 3-O- $\alpha$-L-arabinopyranosyl-(1 $\rightarrow 2)-$ $\alpha$-L-rhamnopyranoside.

\section{INTRODUCTION}

For the past two centuries, peptic ulcers have caused high morbidity and mortality (Malfertheiner, Chan, Mccoll, 2009). This disease is a serious and prevalent pathology (Calam, Baron, 2001). A peptic ulcer is a chronic lesion, usually single, that can be located in the gastric or duodenal mucosae (Kumar, Abbas, Fausto, 2005). In the UK, the incidence of this disease was $12 \%$ higher in men than in women (Araujo, Borini, Guimarães, 2014). A review article (January 1980 to February 2009) showed that the incidence rate of uncomplicated peptic ulcers was approximately one case per 1000 people per year in the general population; the incidence rate for complicated peptic ulcers that included bleeding and perforation was approximately 0.7 cases per 1000 people per year (Lin, Rodrígues, Hernándes-Diaz, 2011).

\footnotetext{
*Correspondence: E. M. Bacchi. Departamento de Farmácia. Faculdade de Ciências Farmacêuticas. Universidade de São Paulo. Av. Prof. Lineu Prestes, 580 - 05508-900 - São Paulo - SP, Brasil. E-mail: elfriede@usp.br
}

The pathophysiology of peptic ulcers suggests that this disease is caused by an imbalance between defensive factors (mucus and bicarbonate secretion, mucosal barrier, blood flow, and prostaglandins) and destructive factors (reactive oxygen species and acid and pepsin secretion), resulting in the acute inflammation of the gastrointestinal mucosae (Laine, Takeuchi, Tarnawski, 2008). Several stimuli serve as offensive factors, including Helicobacter pylori, the use of nonsteroidal anti-inflammatory drugs (NSAIDs), stress, alcohol and cigarette smoking (Malfertheiner, Chan, Mccoll, 2009; Malnick et al., 2014). The current medical treatment for peptic ulcers is generally based on proton pump inhibitors and histamine $\mathrm{H}_{2}$-receptor blockers (Jain et al., 2007). However, the long-term use of these therapeutic agents can produce adverse effects, such as hypergastrinemia and hyperplasia in the enterochromaffinlike (ECL) cells, the risk of pneumonia, diarrhea and the disturbance of human gastrointestinal microflora (Orlando, Lenard, Orlando, 2007; Bays, Finch, 1990; Devault, Talley, 2009; Ksiadzyna, Szelag, Paradowski, 2015). Therefore, the search for safer and more effective alternatives to treat 
gastric ulcers is of paramount importance. Medicinal plants are considered an excellent alternative and have been used to cure ailments for centuries (Zhang et al., 2015). Many studies have reported that medicinal plants and the compounds isolated from them, such as flavonoids, have gastroprotective activities (Awaad, ElMeligy, Soliman, 2013). Unfortunately, there is a lack of complete information regarding the pharmacokinetic factors (absorption, distribution, metabolism and elimination) and pharmacodynamic factors of medicinal plants (Mancuso, 2015). Herbal medicines include many bioactive compounds that can modify drug disposition. One example is the possibility of interactions with drug metabolizing enzymes, such as isoforms of cytochrome P450 (CYP) and UDP-glucuronosyltransferase (UGT) and sulfotransferases (SULT) or transporters (Brantley et al, 2014), leading to the possibility of side-effects, mainly when co-administered with another medication. Polyphenolic compounds are often found in natural products. Their metabolism is mediated by (UGT) in the intestine and liver. The inhibition of UGTs in the intestine, which is the first barrier to oral xenobiotics, by these compounds could alter drug disposition (Roe et al., 2016). Therefore, medical supervision is important because the overuse of herbal medicines can possibly pose health risks (Mancuso, 2015).

Kalanchoe pinnata (Lam.) Pers. (synonym: Bryophyllum pinnatum) (The Plant List, 2015) is a perennial herb. This species is popularly known in Brazil as "folha-da-fortuna," "coirama," "courama," "couramavermelha," and "saião roxo". In Brazil and other parts of the world, it is widely used to treat diarrhea and vomiting, earache, gastric ulcers, burns, abscesses, and insect bites (Almeida et al., 2000; Afzal et al., 2012). The leaves of this plant are reported to possess wound healing (Nayak, Marshall, Isitor, 2010), anti-inflammatory (Ferreira et al., 2014), antioxidant (Hazarika et al., 2012), antimicrobial (El Abdellaoui et al., 2010) and antileishmanial properties (Muzitano et al., 2006a). Pal, Chaudhuri (1991), Adesanwo et al., (2007); Braz, Oliveira, Viana (2013) have reported the antiulcer activity of the methanolic fraction and the methanol and aqueous extract of $K$. pinnata. Phytochemical investigations have shown the presence of tannins, alkaloids and saponins (Biswas et al., 2011), bufadienolides (Yamagishi et al., 1989) and, mainly, flavonoids (Fürer et al., 2013) in K. pinnata.

In this study, we demonstrate the gastroprotective effect of the hydroethanolic extract and the ethyl acetate fraction from the leaves of Kalanchoe pinnata against ethanol-acidified gastric ulcer in rats. In parallel with the pharmacological study, a chemical analysis was performed; flavonoids were shown to be the main compounds in the fraction.

\section{MATERIAL AND METHODS}

\section{Plant material}

The leaves of Kalanchoe pinnata (Lam.) Pers. Crassulaceae were collected at the Chemical, Biological and Agricultural Pluridisciplinary Research CenterCampinas State University (CPQBA-UNICAMP), Paulínia, São Paulo, Brazil. A voucher specimen was deposited at Collection of Medicinal and Aromatic Plants (CQBA-UNICAMP) under the number 337.

\section{Extract preparation}

The fresh leaves were cut into small pieces and dried at $40{ }^{\circ} \mathrm{C}$. The ethanol:water $(7: 3)$ extract was prepared by maceration for 7 days. The extract was concentrated under reduced pressure and then lyophilized. The hydroethanolic extract was partitioned using chloroform, ethyl acetate and water.

\section{HPLC analysis and identification of the compounds}

Briefly, the separation of the ethyl acetate fraction was performed in a Shimadzu ${ }^{\circledR}$ model LC-20 AT instrument with a diode array detector (DAD). The separation was carried out on a $250 \mathrm{~mm}$ x $4.6 \mathrm{~mm}, 5$ $\mu \mathrm{m}$ Shim-pack VP-ODS C18 reverse-phase column $\left(\right.$ Shimadzu $\left.^{\circledR}\right)$. HPLC-grade acetonitrile (solvent B) and purified water with $0.1 \%$ trifluoroacetic acid (solvent A) were used as the mobile phase. The gradient program used was as follows: (1) $5 \%$ solvent B for $0-5$ min and then (2) $5-100 \%$ solvent B for $60 \mathrm{~min}$. The flow rate was $1 \mathrm{~mL} / \mathrm{min}$, $20 \mu \mathrm{L}$ samples $(1 \mathrm{mg} / \mathrm{mL})$ were injected, and the detection occurred at $254 \mathrm{~nm}$. The isolation of the major constituents was achieved on an HPLC semi-preparative UV system $\left(\right.$ Shimadzu ${ }^{\circledR}$ - C18 Shim-pack PREP-ODS $250 \mathrm{~mm} \mathrm{x}$ $20 \mathrm{~mm}, 5 \mu \mathrm{m}$, flow rate $10 \mathrm{~mL} / \mathrm{min}$ ). The mobile phase consisted of $25 \%$ acetonitrile and water with $0.1 \%$ trifluoroacetic acid, and the detection occurred at $254 \mathrm{~nm}$. The major compounds were identified by ${ }^{1} \mathrm{H}$ and ${ }^{13} \mathrm{C}$ NMR spectra on a Bruker Avance DRX-300 $\left({ }^{1} \mathrm{H}: 300 \mathrm{MHz} ;{ }^{13} \mathrm{C}\right.$ : $75 \mathrm{MHz}$ ) using $\mathrm{CD}_{3} \mathrm{OD}$ as the solvent.

\section{Total flavonoid content}

Flavonoids were quantified using the adapted 
methodology of Noriega et al. (2012). Twenty microliters of hydroethanolic extract and ethyl acetate fraction from the $K$. pinnata leaves in $60 \%$ ethanol were added to 20 $\mu \mathrm{L}$ of $2 \% \mathrm{AlCl}_{3}$ in a $96-$ well microplate. A sixty percent ethanol solution was added to bring the volume to $250 \mu \mathrm{L}$. Quercetin was used as a standard for the calibration curve. The absorbance was measured after $30 \mathrm{~min}$ at $430 \mathrm{~nm}$ in a Synergy ${ }^{\mathrm{TM}}$ HT Multi-Detection Microplate Reader. All the analyses were performed in triplicate, and the results were expressed as a quercetin equivalent (mg of quercetin/g of dry weight of test sample).

\section{Total phenolic content}

The total phenolic content was determined using the Folin Ciocalteu method adapted from Ainsworth; Gillepsie (2007). In a 96-well microplate, $20 \mu \mathrm{L}$ of the hydroethanolic extract, ethyl acetate and aqueous fractions from the $K$. pinnata leaves were mixed with $50 \mu \mathrm{L}$ of Folin-Ciocalteu reagent and $100 \mu \mathrm{L}$ of saturated sodium carbonate $(700 \mathrm{mM})$. After two hours, in the absence of light, the absorbance was measured at $765 \mathrm{~nm}$ using a Synergy ${ }^{\text {TM }}$ HT Multi-Detection Microplate Reader. Gallic acid was used for the calibration curve. All the analyses were performed in triplicate, and the results were expressed as gallic equivalent ( $\mathrm{mg}$ of gallic acid/g of dry weight of test sample).

\section{Antioxidant activity}

The scavenging activity of the hydroethanolic extract and ethyl acetate fraction was assessed using the 2,2-diphenyl1-picrylhydrazyl (DPPH) radical (Brand-Williams, Cuvelier, Berset, 1995). Briefly, $50 \mu \mathrm{L}$ of the samples, Trolox ${ }^{\circledR}$ (standard compound) at varying concentrations and 150 $\mu \mathrm{L}$ of DPPH $(175 \mu \mathrm{M})$ were added to a 96 -well microplate. The samples, Trolox ${ }^{\circledR}$ and DPPH were solubilized in $80 \%$ methanol. A control solution, without a test sample, was prepared with DPPH solution and $80 \%$ methanol. All the analyses were completed in triplicate. After 2 hours of reaction with absence of light, the absorbance was measured in a Synergy ${ }^{\mathrm{TM}}$ HT Multi-Detection Microplate Reader at 517 $\mathrm{nm}$. The ability to scavenge the DPPH radical was calculated using the following equation:

$\mathrm{DPPH} \cdot$ Scavenging effect $(\%)=\left[\left(\mathrm{Abs}_{\mathrm{c}}-\mathrm{Abs}_{\mathrm{a}}\right) / \mathrm{Abs}_{\mathrm{c}}\right] \times 100$

where $\mathrm{Abs}_{\mathrm{c}}$ is the absorbance of the control reaction, and $\mathrm{Abs}_{\mathrm{a}}$ is the absorbance of the sample or Trolox ${ }^{\circledR}$.

The $\mathrm{Ec}_{50}$ value was calculated as the concentration of the sample required to scavenge the DPPH radical by $50 \%$.
The ORAC (Oxygen Radical Absorbance Capacity) assay was carried out using an automated microplate reader. Filters were selected for an excitation wavelength of $485 \mathrm{~nm}$ and an emission wavelength of $515 \mathrm{~nm}$. In addition, AAPH was used as a peroxyl radical generator, Trolox $^{\circledR}$ as a standard, and fluorescein as a fluorescent probe. In 96-well microtiter plates, twenty-five microliters of hydroethanolic extract $(10 \mathrm{mg} / \mathrm{mL})$, ethyl acetate fraction $(10 \mathrm{mg} / \mathrm{mL})$ from $K$. pinnata, blank or Trolox ${ }^{\circledR}$ calibration solution $(6.25$ to $100 \mu \mathrm{M})$ were mixed with 150 $\mu \mathrm{L}$ of fluorescein $(40 \mathrm{nM})$ and incubated for $15 \mathrm{~min}$ at 37 ${ }^{\circ} \mathrm{C}$ before injecting $25 \mu \mathrm{L}$ of the AAPH solution (173 mM). The fluorescence was measured every minute for $1 \mathrm{~h}$. The final ORAC values were calculated using the net area under the decay curves. The results were expressed as mmol of Trolox ${ }^{\circledR}$ equivalent (TE)/g of dry weight of the test sample (Prior et al., 2003).

\section{In vivo assays}

Animals

Male Wistar rats (150 to $180 \mathrm{~g}$ ) from the Central Animal House of the School of Pharmaceutical Sciences and the Chemistry Institute of the University of São Paulo were used. The animals were kept under the following standard conditions: (1) food and water ad libitum, (2) 12 $\mathrm{h}$ dark-12 h light, (3) temperature of $22 \pm 2{ }^{\circ} \mathrm{C}$, and (4) 55 $\pm 10 \%$ humidity. The samples (hydroethanolic extract and ethyl acetate fraction), cloprostenol (standard drug) and water (used as the vehicle) were administered by gavage. The Commission of Ethics in Animal Experimentation of FCF-USP approved all the procedures under number 426.

\section{Ethanol/HCl-induced ulcer model}

The procedure was performed according to the method described by Mizui; Doteuchi (1983). The rats were fasted for 12 hours and were kept in cages with raised floors of wide mesh to prevent coprophagy. The animals were divided into the following five treatment groups: (1) vehicle (water $10 \mathrm{~mL} / \mathrm{kg} \mathrm{b.w.),} \mathrm{(2)} \mathrm{cloprostenol} \mathrm{(150} \mathrm{\mu g/}$ $\mathrm{kg}$ ) (Neughebauer et al., 1992), (3) hydroethanolic extract $(100,200$ and $400 \mathrm{mg} / \mathrm{kg})$ and (4) ethyl acetate fraction $(50,100$ and $200 \mathrm{mg} / \mathrm{kg})$. Following 30 minutes of oral treatment with the above samples, the gastric lesions were induced with $300 \mathrm{mmol} / \mathrm{L} \mathrm{HCl}$ in $60 \%$ ethanol $(10 \mathrm{~mL} / \mathrm{kg})$. One hour later, the animals were sacrificed, and the stomachs were removed and opened along the greater curvature. The injuries were analyzed using Image Pro-Plus ${ }^{\circledR}$ software, and a relative lesion area was determined (RLA in \%). The relative lesion area was determined as follows: 
$\mathrm{RLA}=(\mathrm{TLA} \times 100) / \mathrm{TA}$, where TLA $=$ total lesion area $\left(\mathrm{mm}^{2}\right)$, and $\mathrm{TA}=$ total stomach area $\left(\mathrm{mm}^{2}\right)$.

\section{Statistical analysis}

The values were transformed using the square root method to normalize the data distribution. The results were expressed as the mean \pm S.E.M. and analyzed by oneway ANOVA followed by Dunnett's post-hoc test using GraphPad Prism 5 software. The results were considered statistically significant when the $p$-value was less than 0.05 .

\section{RESULTS/DISCUSSION}

The ethanol/HCl-induced ulcer model is a wellestablished method for the evaluation of gastroprotective effects. Ethanol produces an inflammatory response, consequently destroying the stomach-protecting layers and provoking hemorrhagic ulceration of the stomach in experimental animals (Gazzieri et al., 2007; Castro et al., 2010). Moreover, ethanol in contact with gastric mucosa produces oxygen free radicals (Pan et al., 2008). The role of $\mathrm{HCl}$ in the ethanol solution is to accelerate gastric ulcer formation (Mizui, Doteuchi, 1983). The gastroprotective effects of the hydroethanolic extract and ethyl acetate fraction from the leaves of Kalanchoe pinnata were assessed using this model.

The results obtained from the ethanol/ $\mathrm{HCl}$ model showed that the hydroethanolic extract exerted $47 \%$ $(\mathrm{p}<0.01)$ protection on the gastric mucosa at a dose of $400 \mathrm{mg} / \mathrm{kg}$ (Figure 1). Pretreatment with the ethyl acetate fraction at $200 \mathrm{mg} / \mathrm{kg}$ dose significantly inhibited $(\mathrm{p}<0.001)$ gastric ulcers by $50 \%$ (Figure 2$)$. For both experiments, cloprostenol, an analogue of $\mathrm{PGF}_{2}$ alpha, was used as a positive control because it is related to mucosal defense (Neughebauer et al., 1992). Prostaglandins can inhibit gastric acid secretion and stimulate mucus and bicarbonate secretion and mucosal blood flow to promote ulcer healing (Wallace, 2008). A previous study with methanolic extract $(20 \mathrm{mg} / \mathrm{kg}$ and $40 \mathrm{mg} / \mathrm{kg})$ in an ulcer model induced by indomethacin demonstrated inhibition indices of $49.39 \%$ and $71.08 \%$, respectively (Adesanwo et al., 2007). In contrast to this study, other studies using an aqueous extract $(1 \mathrm{~g} / \mathrm{kg}$ and $2 \mathrm{~g} / \mathrm{kg})$ in an indomethacin model and a methanolic fraction $(100 \mathrm{mg} / \mathrm{kg}$ and $300 \mathrm{mg} /$ $\mathrm{kg}$ ) in an ulcer-induction ethanol model of leaves from $K$. pinnata showed the inhibition of gastric lesions by $45.49 \%$ and $49.50 \%$ and $37.5 \%$ and $54.2 \%$, respectively (Pal, Chaudhuri, 1991; Braz, Oliveira, Viana 2013). However, our results showed that the ethyl acetate fraction displayed superior antiulcer activity by $50 \%$ at a dose of
$200 \mathrm{mg} / \mathrm{kg}$. Non-coincident results by different authors can be explained by the use of different extraction solvents. Studies reported that different methods of extraction and solvent systems used to extract bioactive compounds from medicinal plants are an important issue to consider because these factors have an influence on biological activities (Hayouni et al., 2007; Murugan, Parimelazhagan, 2014).

\section{Hydroethanolic Extract - Mean \pm S.E.M.}

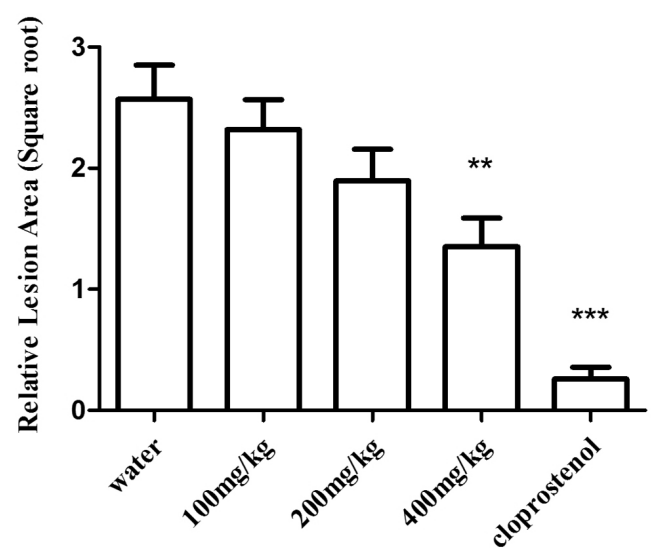

FIGURE 1 - Effect of the hydroethanolic extract from Kalanchoe pinnata leaves on the ethanol/HCl-induced gastric model in Wistar rats. Relative lesion area is presented as the mean \pm S.E.M.; $\mathrm{n}=7$ for each group. ANOVA was carried out and followed by Dunnett's test, ${ }^{* *} p<0.01 ; * * * p<0.001$ compared to water.

Ethyl Acetate Fraction - Mean \pm S.E.M.

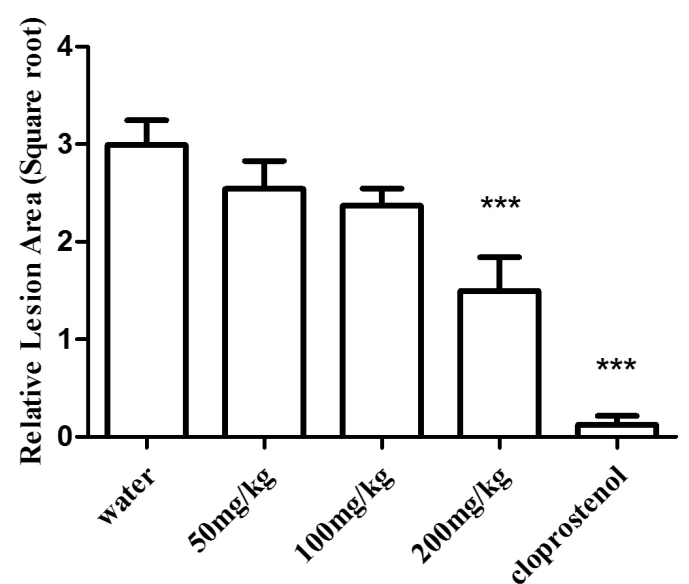

FIGURE 2 - Effect of the ethyl acetate fraction from Kalanchoe pinnata leaves on the ethanol/HCl-induced gastric model in Wistar rats. Relative lesion area is presented as the mean \pm S.E.M.; $n=7$ for each group. ANOVA was carried out and followed by Dunnett's test, ${ }^{* * *} p<0.001$ compared to water.

Chemical analyses were performed with the aim of isolating and identifying the major compounds in the ethyl acetate fraction because this sample showed the 
best results in the antiulcer assay. This study, however, is the first to establish a relationship between the major compounds and their activity. Many studies have shown that flavonoids interact with gastric ulcers. Jung et al., (2007) reported that the flavonoid-rich fraction from Orostachys japonicus (Crassulaceae) reduced $\mathrm{HCl} /$ ethanol-induced gastric lesions and that the anti-ulcer activity could be attributed to the flavonoid compounds. Batista et al., (2013) demonstrated that the flavonoid-rich fraction from Syngonanthus macrolepsis (Eriocaulaceae) at a dose of $100 \mathrm{mg} / \mathrm{kg}$ protected the gastric mucosa in animals, most likely due to the involvement of sulfhydryl compounds and the antioxidant system.

In our study, the HPLC-DAD analysis (Figure 3) of the ethyl acetate fraction indicated two major compounds (1 and 2). These substances were isolated and identified by ${ }^{1} \mathrm{H}$ and ${ }^{13} \mathrm{C}$ NMR (using $\mathrm{CD}_{3} \mathrm{OD}$ as the solvent).

Compound 1 (Figure 4) was identified as quercetin 3-O- $\alpha$-L-arabinopyranosyl- $(1 \rightarrow 2)$ - $\alpha$-L-rhamnopyranoside by ${ }^{1} \mathrm{H}$ NMR (300 MHz) and ${ }^{13} \mathrm{C}$ NMR (75 MHz). ${ }^{1} \mathrm{H}-\mathrm{NMR}$ $\left(\mathrm{CD}_{3} \mathrm{OD}, 300 \mathrm{MHz}\right)$ spectra showed peaks at $\delta 7.37(\mathrm{~d}, J$ $=1.8 \mathrm{~Hz}, \mathrm{H}-2^{\prime}$ ), 7.00 (dd, $J=8.4,2.1 \mathrm{~Hz}, \mathrm{H}-6$ '), 6.93 (d, $J$ $=8.4 \mathrm{~Hz}, \mathrm{H}-5$ '), $6.37(\mathrm{~d}, J=2.1 \mathrm{~Hz}, \mathrm{H}-8), 6.21(\mathrm{~d}, J=2.1$ Hz, H-6), 5.38 (d, $J=0.9 \mathrm{~Hz}, \mathrm{H}-1$ "), 4.21 (d, $J=7.2 \mathrm{~Hz}$, H-1"”), 4.19 (m, H-2"), 3.9 (m, H-3"), 3.8 (m, H-5"), 3.74 (m, H-4"'), 3.66 (dd, $J=12.9,2.0 \mathrm{~Hz}, \mathrm{H}-5$ "'), 3.56 (dd, $J=$ 9.3, 7.2 Hz, H-2"'), 3.47 (dd, $J=9.3,3 \mathrm{~Hz}, \mathrm{H}-3$ "'), 3.39 (d, $J=11.4 \mathrm{~Hz}, \mathrm{H}-5$ "'), 3.35 (dd, $J=9.3,9.3 \mathrm{~Hz}, \mathrm{H}-4$ "'), and 1.02 (d, $J=6.3 \mathrm{~Hz}, \mathrm{H}-6$ ") $){ }^{13} \mathrm{C}-\mathrm{NMR}\left(\mathrm{CD}_{3} \mathrm{OD}, 75 \mathrm{MHz}\right)$ showed peaks at $\delta 179.85$ (C-4), 165.86 (C-7), 163.25
(C-9), 159.21 (C-5), 158.55 (C-2), 149.86 (C-4'), 146.52 (C-3'), 136.88 (C-3), 122.99 (C-1'), 122.77 (C-6'), 116.91 (C-2'), 116.55 (C-5'), 107.83 (C-1'”), 105.91 (C-10), 103.28 (C-1"), 99.88 (C-6), 94.81 (C-8), 82.72 (C-2”), 74.37 (C-4"), 73.84 (C-3"”), 72.86 (C-2"”), 72.06 (C-5"), 71.82 (C-3"), 69.90 (C-4"'), 67.47 (C-5"'), and 17.76 (C6 "). Our results were compared and were consistent with the results presented by Muzitano et al. (2006a), who also reported that quercetin 3-O- $\alpha$-L-arabinopyranosyl- $(1 \rightarrow 2)$ $\alpha$-L-rhamnopyranoside may be a chemical marker for $K$. pinnata because it is not common in other plant species, except for Alphitonia philippinensis (Rhamnaceae) and Rollinia emarginata (Annonaceae) (Jou et al., 2004; Roth et al., 2011).

Compound 2 (Figure 4) was identified as quercitrin. Our results were compared and found to be consistent with those described by Hanamura; Hagiwara; Kawagishi (2005) [47]. ${ }^{1} \mathrm{H}-\mathrm{NMR}\left(\mathrm{CD}_{3} \mathrm{OD}, 300 \mathrm{MHz}\right)$ spectra showed peaks at $\delta 7.35\left(\mathrm{~d}, \mathrm{~J}=1.7 \mathrm{~Hz}, \mathrm{H}-2^{\prime}\right), 7.30(\mathrm{dd}, J=8.3,1.8$ Hz, H-6'), 6.92 (d, $J=8.3 \mathrm{~Hz}, \mathrm{H}-5$ '), 6.35 (d, $J=1.7 \mathrm{~Hz}$, H-8), 6.19 (d, $J=1.5 \mathrm{~Hz}, \mathrm{H}-6$ ), 5.36 (s, H-1"), 4.25 (s br, H-2"), 3.78 (dd, $J=9,3.2 \mathrm{~Hz}, \mathrm{H}-3$ "), 3.43 (dd, $J=9.6,6$ $\mathrm{Hz}, \mathrm{H}-5$ '), 3.35 (t, $J=9 \mathrm{~Hz}, \mathrm{H}-4$ "'), and 0.95 (d, $J=6.4$ $\mathrm{Hz}, \mathrm{H}-6$ ") $){ }^{13} \mathrm{C}-\mathrm{NMR}\left(\mathrm{CD}_{3} \mathrm{OD}, 75 \mathrm{MHz}\right)$ showed peaks at $\delta 179.68(\mathrm{C}-4), 165.82$ (C-7), 163.18 (C-5), 159.37 (C-2), 158.52 (C-9), 149.79 (C-4'), 146.41 (C-4'), 136.32 (C3), 123.10 (C-6'), 123.05 (C-1'), 117.13 (C-5'), 116.51 (C-2'), 103.58 (C-1'), 99.95 (C-6), 94.88 (C-8), 73.39 (C-4"), 72.24 (C-2"), 72.10 (C-3"), 71.99 (C-5"), and 17.77 (C-6").

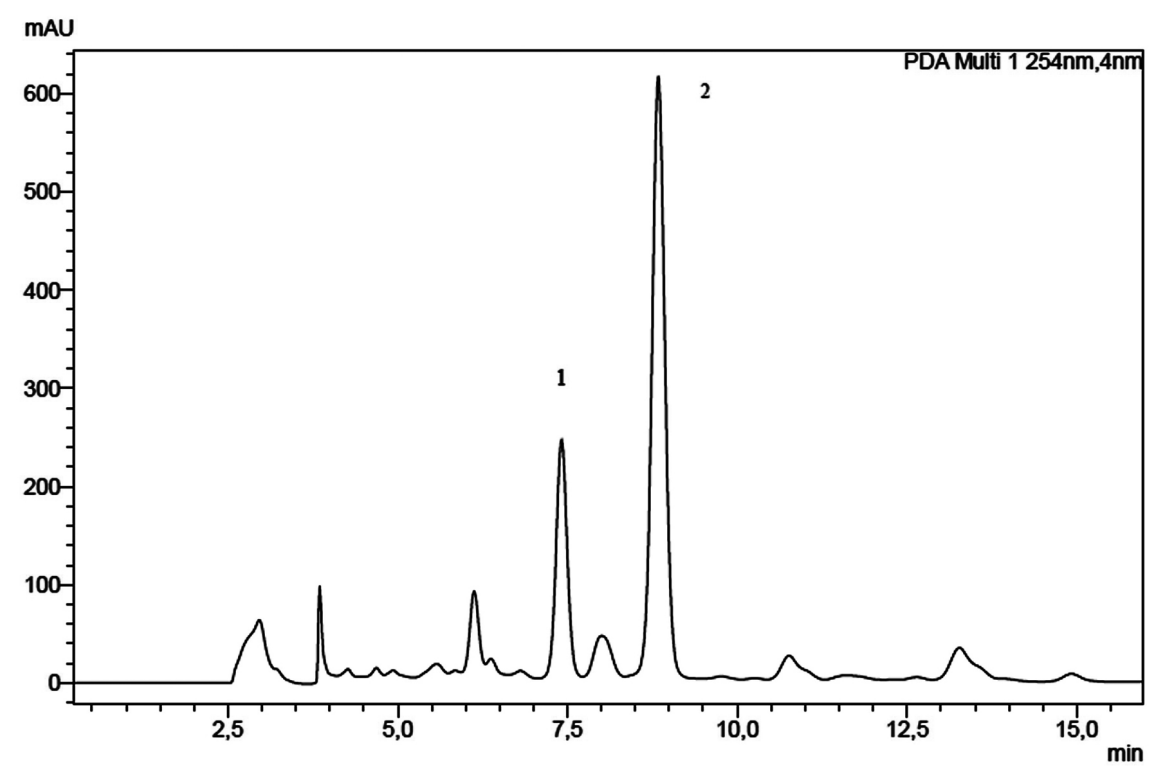

FIGURE 3 - HPLC-DAD $(\lambda=254 \mathrm{~nm})$ separation of the ethyl acetate fraction from Kalanchoe pinnata leaves. The separation was carried out on a Shimadzu LC-20A series, $250 \mathrm{~mm}$ x $4.6 \mathrm{~mm}, 5 \mu \mathrm{m}$ Shim-pack VP-ODS C18 reverse-phase column (Shimadzu ${ }^{\circledR}$ ), at flow rate of $1 \mathrm{~mL} / \mathrm{min}$. Isocratic elution ( $25 \%$ acetonitrile and water with $0.1 \%$ trifluoroacetic acid) in $15 \mathrm{~min}$. 


\section{Compound 1}

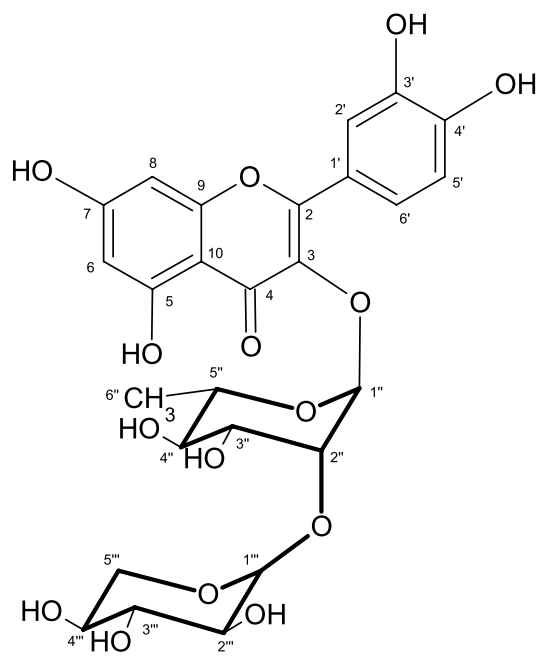

\section{Compound 2}

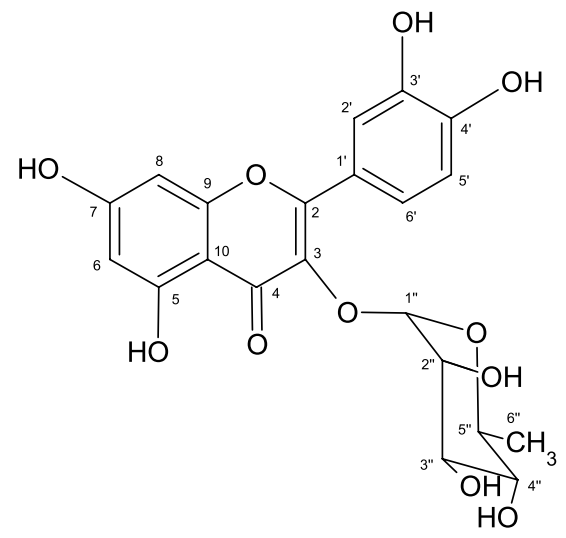

FIGURE 4 - Structural formulas of compound 1 quercetin 3-O- $\alpha$-L-arabinopyranosyl-(1 $\rightarrow 2)-\alpha$-L-rhamnopyranoside and compound 2 quercitrin isolated from the Kalanchoe pinnata leaves.

The isolated compounds are flavonoids. Flavonoids are phenolic substances with many health properties that frequently have antioxidant activities as well (Benavente-García et al., 1997). Previous studies have shown that $K$. pinnata is an important source of phenolic compounds, mainly flavonoids (Costa et al., 2008). Many flavonoids have been previously described in this species, including the compounds isolated in this study (Muzitano et al., 2006a, 2006b; Tatsimo et al., 2012). The literature reports that compound 1 (diglycosylated flavonoid) showed antiallergic actions (Ichikawa, Ogura, Lijima, 1986), high antioxidant potential (Nascimento et al., 2013) and antileishmanial activities (Muzitano et al., 2006a). Moreover, quercetrin (2) protected skin from UVB-induced inflammation (Yin et al., 2013), displayed antioxidant (Aderogba, Okoh, Idowu, 2005; Tai et al., 2014) and antileishmanial activities (Muzitano et al., 2006b), showed antiproliferative and apoptotic effects in colon cancer cells (Cincin et al., 2015), demonstrated gastroprotective actions (Mota et al., 2009) and showed intestinal anti-inflammatory effects (Camuesco et al., 2004). Júnior et al., (2014) reported that quercitrin was present in Croton campestris extracts at $2.34 \%$ and might be involved in gastroprotective activities against ethanol, acidified ethanol-, and indomethacin-induced gastric lesions. This antiulcer effect seems to be mediated by NO and endogenous prostaglandin pathways. Quercetin is a structure common to both isolated compounds in our lab. This molecule could be responsible for antiulcer activity. Kahraman et al., (2003) found that the treatment of rats with quercetin $(200 \mathrm{mg} / \mathrm{kg})$ inhibited ethanol-induced gastric lesions and suggested that antiperoxidative and antihistaminic effects and antioxidant mechanisms mediated this effect. Quercetin was also related to gastroprotection in indomethacin-induced gastric damage (Shakeerabanu et al., 2011).

In our experiments, the total amount of flavonoid and phenolic compounds in the ethyl acetate fraction was higher than that in the hydroethanolic extract and aqueous fractions (Table I). Because many studies revealed a relationship between phenolic compounds and antioxidant activity (Popa et al., 2012; Jemia et al., 2013), the antioxidant activity was also assessed to determine the possible mechanisms of action.

The antioxidant activity of flavonoids plays an important role in gastroprotective activities (AlvarezSuarez et al., 2011). Studies have demonstrated that these compounds can scavenge superoxide, hydroxyl and peroxyl radicals. Moreover, they are involved in lipid peroxidation inhibition, mucus production, decrease of histamine levels and inhibition of gastric acid secretion (Priya, Parminder, Jaspreet, 2012; Repetto, Llesuy, 2002). Li et al., (2015) reported that the flavonoids from Abrus cantoniensis extracted with ethanol had an antiulcer effect, probably due to their antioxidant activity.

There are two methods of measuring total antioxidant capacity: assays based on hydrogen atom transfer (HAT), such as ORAC, and assays based on electron transfer (ET), such as DPPH. It is advisable to use two or more different methods of antioxidant capacity measurement because of the different mechanisms of action of antioxidants (Huang, Ou, Prior, 2005). The results of the antioxidant capacity 
Gastroprotective activity of the hydroethanolic extract and ethyl acetate fraction from Kalanchoe pinnata (Lam.) Pers.

TABLE I - Total flavonoid and phenolic compound content in the hydroethanolic extract and the ethyl acetate fraction from Kalanchoe pinnata leaves. The data shown as the mean \pm S.E.M. ; $\mathrm{n}=3$.

\begin{tabular}{lcc}
\hline Sample & Total Flavonoid Content $^{\mathbf{a}}$ & Total Phenolic Content $^{\mathbf{b}}$ \\
\hline Hydroethanolic extract & $36.9 \pm 4.0$ & $149.6 \pm 2.2$ \\
Ethyl acetate fraction & $164.3 \pm 5.4$ & $363.3 \pm 6.4$ \\
\hline
\end{tabular}

${ }^{a}$ Total flavonoid content is expressed as the mean \pm S.E.M. mg of quercetin/g of dry weight. ${ }^{b}$ Total phenolic content is expressed as the mean \pm S.E.M. mg of gallic acid/g of dry weight.

experiments by DPPH showed that the ethyl acetate fraction $\left(\mathrm{CE}_{50}=41.91 \mu \mathrm{g} / \mathrm{mL}\right)$ was more active than the hydroethanolic extract $\left(\mathrm{CE}_{50}=72.63 \mu \mathrm{g} / \mathrm{mL}\right)$. The $\mathrm{CE}_{50}$ of Trolox ${ }^{\circledR}$, the reference compound, was $\left(\mathrm{CE}_{50}=33.38 \mu \mathrm{g} / \mathrm{mL}\right)$. However, Tatismo et al., (2012) found that the antioxidant activity of the $\mathrm{MeOH}$ extract of $K$. pinnata $\left(\mathrm{CE}_{50}=52.48 \mu \mathrm{g} / \mathrm{mL}\right)$ was higher than that of the ethyl acetate fraction $\left(\mathrm{CE}_{50}=78.11 \mu \mathrm{g} / \mathrm{mL}\right)$. The values obtained by the ORAC method for the hydroethanolic extract and the ethyl acetate fraction were $4.31 \mathrm{mmol} \mathrm{TE} / \mathrm{g}$ and $11.33 \mathrm{mmol} \mathrm{TE} / \mathrm{g}$, respectively. The antioxidant capacity was higher in the ethyl acetate fraction in both assays (DPPH and ORAC).

These data suggest that the gastroprotective effect is due, at least partially, to flavonoids and the antioxidant capacity of these substances in all samples tested.

\section{CONCLUSION}

Our results provide evidence for the popular use of Kalanchoe pinnata in treating gastric ulcer. This can be confirmed by the gastroprotective potential of $K$. pinnata in the animal model. The ethyl acetate fraction reduced gastric lesions by $50 \%$ at a dose of $200 \mathrm{mg} / \mathrm{kg}$, most likely due to the high amounts of phenolic and flavonoid compounds present in this fraction. Studies are currently being conducted by our group to investigate the mechanisms of action of the flavonoid fraction present in this species.

\section{ACKNOWLEDGMENTS}

We are grateful to Ílio Montanari Júnior (CPQBAUNICAMP) for providing the vegetal material. We would also like to thank Prof ${ }^{a}$ Dr $^{a}$ Silvia Berlanga de Moraes Barros from FCF/USP for allowing us to use the Synergy ${ }^{\mathrm{TM}}$ HT Multi-Detection Microplate Reader and Prof ${ }^{a} \mathrm{Dr}^{\mathrm{a}}$ Ivana Barbosa Suffredini from UNIP for allowing us to use the freeze dryer. This work was supported by Capes.

\section{REFERENCES}

ADEROGBA, M.A.; OKOH, E.K., IDOWU, T.O. Evaluation of the antioxidant activity of the secondary metabolites from Piliostigma reticulatum (DC.) hochst. J. Biol. Sci., v.5, p.239-242, 2005.

ADESANWO, J.K.; RAJI, Y.; OLALEYE, S.B.; ONASANWO, S.A. Antiulcer activity of methanolic extract of Bryophyllum pinnatum in rats. J. Biol. Sci., v.7, n.2, p.409-412, 2007.

AFZAL, M.; KAZMI, I.; KHAN, R.; SINGH, R.; CHAUHAN, M.; BISHT, T.; ANWAR, F. Bryophyllum pinnatum: a review. Int. J. Biol. Sci., v.2, n.4, p.143-149, 2012.

AINSWORTH, E.A.; GILLESPIE, K.M. Estimation of total phenolic content and other oxidation substrates in plants tissues using Folin-Ciocalteau reagent. Nat. Protoc., v.2, n.4, p.875-877, 2007.

ALMEIDA, A.P.; SILVA, S.A.; SOUZA, M.L.; LIMA, L.M.; ROSSI-BERGMANN, B.; MORAES, V.L.; COSTA S.S. Isolation and chemical analysis of a fatty acid fraction of Kalanchoe pinnata with a potent Lymphocyte supressive activity. Planta Med., v.66, n.2, p.134-137, 2000.

ALVAREZ-SUAREZ, J.M.; DEKANSKI, D.; RISTIC, S.; RADONJIC, N.V.; PETRONIJEVIC, N.D.; GIAMPIERI, F.; ASTOLFI, P.; GONZÁLEZ-PARAMÁS, A.M.; SANTOS-BUELGA, C.; TULIPANI, S.; QUILES, J.L.; MEZZETI, B.; BATTINO, M. Strawberry polyphenols attenuate ethanol-induced gastric lesions in rats by activation of antioxidant enzymes and attenuation of MDA increase. PLoS One., v.6, n.10, p.1-11, 2011.

ARAUJO, M.B.; BORINI, P.; GUIMARÃES, R.C. Etiopathogenesis of peptic ulcer: back to the past? Arq. Gastroenterol., v.51, n.2, p.155-161, 2014. 
AWAAD, A.S.; EL-MELIGY, R.M.; SOLIMAN, G.A. Natural products in treatment of ulcerative colitis and peptic ulcer. J. Saudi Chem. Soc., v.17, p.101-124, 2013.

BATISTA, L.M.; ALMEIDA, A.B.A.; LIMA, G.R.M.; FALCÃO, H.S.; MAGRI, L.P.; LUIZ-FERREIRA, A.; SANTOS, L.C.; HIRUMA-LIMA, C.A.; VILEGAS, W.; BRITO, A.R.M.S. Gastroprotective effect (in rodents) of a flavonoid rich fraction obtained from Syngonanthus macrolepsis. J. Pharm. Pharmacol., v.66, n.3, p.445-452, 2013.

BAYS, D.E.; FINCH, H. Inhibitors of gastric acid secretion. Nat. Prod. Rep., v.7, p.409-445, 1990.

BENAVENTE-GARCÍA, O.; CASTILHO, J.; MARIN, F.R.; ORTUÑO, A.; DEL RÍO, J.A. Uses and properties of Citrus flavonoids. J. Agric. Food Chem., v.45, n.12, p.4505-4515, 1997.

BISWAS, S.K.; CHOWDHURY, A.; DAS, J.; KARMAKAR, U.K.; SHILL, M.C. Assessment of cytotoxicity and antibacterial activities of ethanolic extracts of Kalanchoe pinnata Linn. (Family: Crassulaceae) leaves and stems. IJPSR, v.2, n.10, p.2605-2609, 2011.

BRAND-WILLIAMS, W.; CUVELIER, M.E.; BERSET, C. Use of a free radical method to evaluate antioxidant activity. LWT-Food Sci. Technol., v.28, p.25-30, 1995.

BRANTLEY, S.J.; ARGIKAR, A.A.; LIN, Y.S.; NAGAR, S.; PAINE, M.F. Herb-drug interactions: challenges and opportunities for improved predictions. Drug Metab. Dispos, v.42, n.3, p.301-317, 2014.

BRAZ, D.C.; OLIVEIRA, L.R.S.; VIANA, A.F.S.C. Atividade antiulcerogênica do extrato aquoso da Bryophyllum pinnatum (Lam.) Kurz. Rev. Bras. Plantas Med., v.15, n.1, p.86-90, 2013.

CALAM, J.; BARON, J.H. Pathophysiology of duodenal and gastric ulcer and gastric cancer. BMJ., v.323, p.980-982, 2001 .

CAMUESCO, D.; COMALADA, M.; RODRÍGUESCABEZAS, M.E.; NIETO, A.; LORENTE, M.D.; CONCHA, A.; ZARZUELO, A.; GÁLVEZ, J. The intestinal anti-inflammatory effect of quercitrin is associated with an inhibition in iNOS expression. Br. J. Pharmacol., v.143, n.7, p.908-918, 2004.
CASTRO, G.A.; CARVALHO, J.E.; TINTO, S.V.; POSSENTI, A.; SGARBIERI, V.C. Anti-ulcerogenic effect of a whey protein isolate and collagen hydrolysates against ethanol ulcerative lesions on oral administration to rats. J. Med Food., v.13, n.1, p.83-90, 2010.

CINCIN, Z.B.; UNLU, M.; KIRAN, B.; BIRELLER, E.S.; BARAN, Y.; CAKMAKOGLU, B. 2014. Apoptotic effects of quercitrin on DLD-1 colon cancer cell line. Pathol. Oncol. Res., v. 21, n.2, p.333-338, 2015.

COSTA, S.S.; MUZITANO, M.F.; CAMARGO, L.M.M.; COUTINHO, M.A.S. Therapeutic potential of Kalanchoe species: flavonoids and other secondary metabolites. Nat. Prod. Com., v.3, n.12, p.2151-2164, 2008.

DEVAULT, K.R.; TALLEY, N.J. Insights into the future of gastric acid suppression. Nat. Rev. Gastroenterol. Hepatol., v.6, n.9, p.524-532, 2009.

EL ABDELLAOUI, S.; DESTANDAU, E.; TORIBIO, A.; ELFAKIR, C.; LAFOSSE, M.; RENIMEL, I.; ANDRÉ, P.; CANCELLIERI, P.; LANDEMARRE, L. Bioactive molecules in Kalanchoe pinnata leaves: extraction, purification, and identification. Anal. Bioanal. Chem., v.398, n.3, p.1329-1338, 2010.

FERREIRA, R.T.; COUTINHO, M.A.S.; MALVAR, D.C.; COSTA, E.A.; FLORENTINO, I.F.; COSTA, S.S.; VANDERLINDE, F.A. Mechanisms underlying the antinociceptive, antiedematogenic, and anti-inflammatory activity of main flavonoid from Kalanchoe pinnata. Evid. Based Complement Alternat. Med.,v.2014, art.429256, 2014.

FÜRER, K.; RAITH, M.; BRENNEISEN, R.; MENNET, M.; SIMÕES-WÜST, A.P.; VON MANDACH, U.; HAMBURGUER, M.; POTTERAT, O. Two new flavonol glycosides and a metabolite profile of Bryophyllum pinnatum, a phytotherapeutic used in obstetrics and gynaecology. Planta Med., v.79, n.16, p.1565-1571, 2013.

GAZZIERI, D.; TREVISANI, M.; SPRINGER, J.; HARRISON, S.; COTTREL, G.S.; ANDRE, E.; NICOLETTI, P.; MASSI, D.; ZECCHI, S.; NOSI, D.; SANTUCCI, M.; GERARD, N.P.; LUCATTELLI, M.; LUNGARELLA, G.; FISCHER, A.; GRADY, E.F.; BUNNETT, N.W.; GEPPETTI, P. Substance P released by TRPV1-expressing neurons produces reactive oxygen species that mediate ethanolinduced gastric injury. Free Radic. Biol. Med., v.43, n.4, p.581-589, 2007. 
HANAMURA, T.; HAGIWARA, T.; KAWAGISHI, H. Structural and functional characterization of polyphenols isolated from acerola (Malpighia emarginata DC.) fruit. Biosci. Biotechnol. Biochem., v.69, n.2, p.280-286, 2005.

HAYOUNI, E.A.; ABEDRABBA, M.; BOUIX, M.; HAMDI, $M$. The effects of solvents and extraction method on the phenolics contents and biological activities in vitro of Tunisian Quercus coccifera L. and Juniperus phoenicea L. fruit extracts. Food Chem., v.105, n.3, p.1126-1134, 2007.

HAZARIKA, N.; SINGH, P.; HUSSAIN, A.; DAS, S. Phenolics content and antioxidant activity of crude extract of Oldenlandia corymbosa and Bryophyllum pinnatum. RJPBCS, v.3, n.2, p.297-303, 2012.

HUANG, D.; OU, B.; PRIOR, R.L. The chemistry behind antioxidant capacity assays. J. Agric. Food Chem., v.53, n.6, p.1841-1856, 2005.

ICHIKAWA, M.; OGURA, M.; LIJIMA, T. Antiallergic flavones glycoside from Kalanchoe pinnatum. Jpn. Kokai Tokkyo Koho JP 61,118,396, apud Chemical Abstract 105: $178423 q, 1986$.

JAIN, K.S.; SHAH, A.K.; BARIWAL, J.; SHELKE, S.M.; KALE, P.A.; JAGTAP, J.R.; BHOSALE, A.V. Recent advances in proton pump inhibitors and management of acid-peptic disorders. Bioorg. Med. Chem., v.15, n.3, p.1181-1205, 2007.

JEMIA, M.B.; WANNES, W.A.; OUCHIKH, O.; BRUNO, M.; KCHOUK, M.E. Antioxidant activity of Tunisian Geranium robertianum L. (Geraniaceae). Nat. Prod. Res., v.27, n.22, p.2076-2083, 2013.

JOU, S.J.; CHEN, C.H.; GUH, J.H.; LEE, C.N.; LEE, S.S. Flavonol glycosides and cytotoxic triterpenoids from Alphitonia philippinensis. J. Chin. Chem Soc., v.51, n.4, p.827-834, 2004.

JUNG, H.J.; CHOI, J.; NAM, J.H.; PARK, H.J. Anti-ulcerogenic effects of the flavonoids-rich fraction from the extract of Orostachys japonicus in mice. J. Med. Food., v.10, n.4, p.702-706, 2007.
JÚNIOR, F.E.B.; OLIVEIRA, D.R.; BOLIGON, A.A.; ATHAYDE, M.L.; KAMDEM, J.P.; MACEDO, G.E.; SILVA, G.F.; MENEZES, I.R.A.; COSTA, J.G.M.; COUTINHO, H.D.M.; KERNTOPF, M.R.; POSSER, T. Protective effects of Croton campestris A. St-Hill in different ulcer models in rodents: evidence for the involvement of nitric oxide and prostaglandins. J. Ethnopharmacol., v.153, n.2, p.469-477, 2014.

KAHRAMAN, A.; ERKASAP, N.; KÖKEN, T.; SERTESER, M.; AKTEPE, F.; ERKASAP, S. The antioxidative and antihistaminic properties of quercetin in ethanol-induced gastric lesions. Toxicology, v.183, n.1/3, p.133-142, 2003.

KSIADZYNA, D.; SZELAG, A.; PARADOWSKI, L. Overuse of proton pump inhibitors. Pol. Arch. Med. Wewn., v.125, n.4, p.289-298, 2015.

KUMAR, V.; ABBAS, A.K.; FAUSTO, N. Robbins \& Cotran pathologic basis of disease. 7.ed. Philadelphia: Elsevier Saunders, 2005. 816 p.

LAINE, L.; TAKEUCHI, K.; TARNAWSKI, A. Gastric mucosal defense and cytoprotection: bench to bedside. Gastroenterology, v.135, n.1, p.41-60, 2008.

LI, H.; SONG, Z.J.; DAI, Y.P.; ZHANG, S.L.; HE X.; GUO, C.R.; ZHANG, W.J.; WANG, J.Y.; ZHANG, C.F.; WANG, C.Z.; YUAN, C.S. Antioxidative activity of flavonoids from Abrus cantoniensisagainst ethanol-induced gastric ulcer in mice. Planta Med., v.81, n.10, p.784-790, 2015.

LIN, K.J.; RODRÍGUES, L.A.G.; HERNÁNDES-DIAZ, S. Systematic review of peptic ulcer disease incidence rates: do studies without validation provide reliable estimates? Pharmacoepidemiol. Drug Saf., v.20, n.7, p.718-728, 2011.

MALFERTHEINER, P.; CHAN, F.K.; MCCOLL, K.E. Peptic ulcer disease. Lancet, v.374, n.9699, p.1449-1461, 2009.

MALNICK, S.D.H.; MELZER, E.; ATTALI, M.; DUEK, G.; YAHAV, J. Helicobacter pylori: friend or foe? World J. Gastroenterol., v.20, n.27, p.8979-8985, 2014.

MANCUSO, C. Key factors which concur to the correct therapeutic evaluation of herbal products in free radicalinduced diseases. Front. Pharmacol., v.6, n.86, p.1-8, 2015.

MIZUI, T.; DOTEUCHI, M. Effect of polyamines on acidified ethanol-induced gastric lesion in rats. Jpn. J. Pharmacol, v.33, n.5, p.939-945, 1983. 
MOTA, K.S.L.; DIAS, G.E.N.; PINTO, M.E.F.; LUIZFERREIRA, A.; SOUZA-BRITO, A.R.M.; HIRUMALIMA, C.A.; BARBOSA-FILHO, J.M.; BATISTA, L.M. Flavonoids with gastroprotective activity. Molecules, v.14, n.3, p.979-1012, 2009.

MURUGAN, R.; PARIMELAZHAGAN, T. Comparative evaluation of different extraction methods for antioxidant and anti-inflammatory properties from Osbeckia parvifolia Arn.- An in vitro approach. J. King Saud Univ. Sci., v.26, n.4, p.267-275, 2014.

MUZITANO, M.F.; TINOCO, L.W.; GUETTE, C.; KAISER, C.R.; ROSSI-BERGMANN, B.; COSTA, S.S. The antileishmanial activity assessment of unusual flavonoids from Kalanchoe pinnata. Phytochemistry, v.67, n.18, p.2071-2077, 2006a.

MUZITANO, M.F.; CRUZ, E.A.; ALMEIDA, A.P.; SILVA, S.A.; KAISER, C.R.; GUETTE, C.; ROSSI-BERGMANN, B.; COSTA, S.S. Quercitrin: an antileishmanial flavonoid glycoside from Kalanchoe pinnata. Planta Med., v.72, n.1, p.81-83, $2006 b$.

NASCIMENTO, L.B.; LEAL-COSTA, M.V.; COUTINHO, M.A.; MOREIRA, N.S.; LAGE, C.L.; BARBI, N.S.; COSTA, S.S.; TAVARES, E.S. Increased antioxidant activity and changes in phenolic profile of Kalanchoe pinnata (Lamarck) Persoon (Crassulaceae) specimens grown under supplemental blue light. Photochem. Photobiol., v.89, n.2, p.391-399, 2013.

NAYAK, B.S.; MARSHALL, J.R.; ISITOR, G. Wound healing potential of ethanolic extract of Kalanchoe pinnata Lam. leaf- a preliminary study. Indian J. Exp. Biol., v.48, n.6, p.572-576, 2010.

NEUGHEBAUER, B.I.; NECHIFOR, M.; DOBRESCU, G.; NEGRU, A.; ADOMNICAI, M. Influence of cloprostenol in the experimentally induced ulcer in rats. Rev. Med. Chir. Soc. Med. Nat. Lasi., v.96, suppl., p.10-12, 1992.

NORIEGA, P.; MAFUD, D.F.; SOUZA, B.; SOARES-SCOTT, M.; RIVELLI, D.P.; BARROS, S.B.; BACCHI, E.M. Applying design of experiments (DOE) to flavonoid extraction from Passiflora alata and P. edulis. Braz. J. Pharmacogn., v.22, n.5, p.1119-1129, 2012.

ORLANDO, L.A.; LENARD, L.; ORLANDO, R.C. Chronic hypergastrinemia: causes and consequences. Dig. Dis. Sci., v.52, n.10, p.2482-2489, 2007.
PAL, S.; CHAUDHURI, A.K.N. Studies on the anti-ulcer activity of a Bryophyllum pinnatum leaf extract in experimental animals. J. Ethnopharmacol., v.33, n.1/2, p.97-102, 1991.

PAN, J.S.; HE, S.Z.; XU, H.Z.; YANG, X.N.; XIAO, H.M.; SHI, H.X.; REN, J.L. Oxidative stress disturbs energy metabolism of mitochondria in ethanol-induced gastric mucosa injury. World J. Gastroenterol., v.14, n.38, p.5857$5867,2008$.

POPA, C.P.; LUNGU, L.; SAVOIU, M.; BRADU, C.; DINOIU, V.; DANET, A.F. Total antioxidant activity and phenols and flavonoids content of several plant extracts. Int. J. Food Prop., v.15, n.3, p.691-701, 2012.

PRIOR, R.L.; HOANG, H.; GU, L.; WU, X.; BACCHIOCCA, M.; HOWARD, L.; HAMPSCH-WOODILL, M.; HUANG, D.; OU, B.; JACOB, R. Assays for hydrophilic and lipophilic antioxidant capacity (oxygen radical absorbance capacity $\left(\mathrm{ORAC}_{\mathrm{FL}}\right)$ of plasma and other biological and food samples. J. Agric. Food Chem., v.51, n.11, p.3273-3279, 2003.

PRIYA, G.; PARMINDER, N.; JASPREET, S. Oxidative stress induced ulcer protected by natural antioxidants: a review. IRJP, v.3, n.5, p.76-81, 2012.

REPETTO, M.G.; LLESUY, S.F. Antioxidant properties of natural compounds used in popular medicine for gastric ulcers. Braz. J. Med. Biol. Res., v.35, v.5, p.523-534, 2002.

ROE, A.L.; PAINE, M.F.; GURLEY, B.J.; BROUWER, K.R.; JORDAN, S.; GRIFFITHS, J.C. Assessing natural productsdrug interactions: An end-to-end safety framework. Regul. Toxicol. Pharmacol., v.76, p.1-6, 2016.

ROTH, M.; ARAYA J.J.; TIMMERMANN, B.N.; HAGENBUCH, B. Isolation of modulators of the liver-specific organic anion-transporting polypeptides (OATPs) 1B1 and 1B3 from Rollinia emarginata Schlecht (Annonaceae). J. Pharmacol. Exp. Ther., v.339, n.2, p.624$632,2011$.

SHAKEERABANU, M.; SUJATHA, K.; RAJNEESH, C.P.; MANIMARAM, A. The defensive effect of quercetin on indomethacin induced gastric damage in rats. Adv. Biol. Res.,v.5, n.1, p.64-70, 2011. 
TAI, Z.; CHEN, A.; QIN, B.; CAI, L.; XU, Y. Chemical constituents and antioxidant activity of the Musa basjoo flower. Eur. Food Res. Technol., v.239, n.3, p.501-508, 2014.

TATSIMO, S.J.; TAMOKOU, J.D.; HAVYARIMANA, L.; CSUPOR, D.; FORGO, P.; HOHMANN, J.; KUIATE, J.R.; TANE, P. Antimicrobial and antioxidant activity of kaempferol rhamnoside derivates from Bryophyllum pinnatum. BMC Res. Notes, v.5, p.158, 2012.

THE PLANT LIST. Version 1. Available from: <http://www. theplantlist.org/>. Access in: 05 Nov. 2015.

WALLACE, J.L. Prostaglandins, NSAIDs, and gastric mucosal protection: why doesn't the stomach digest itself? Physiol. Rev., v.88, n.4, p.1547-1565, 2008.

YAMAGISHI, T.; HARUNA, M.; YAN, X.Z.; CHANG, J.J.; LEE, K.H. Antitumor agents, 110. Bryophyllin B, a novel potent cytotoxic bufadienolide from Bryophyllum pinnatum. J. Nat. Prod., v.52, n.5, p.1071-1079, 1989.
YIN, Y.; LI, W.; SON, Y.O.; SUN, L.; LU, J.; KIM, D.; WANG, X.; YAO, H.; WANG, L.; PRATHEESHKUMAR, P.; HITRON, A.J.; LUO, J.; GAO, N.; SHI, X.; ZHANG, Z. Quercitrin protects skin from UVB-induced oxidative damage. Toxicol. Appl. Pharmacol., v.269, n.2, p.89-99, 2013.

ZHANG, Q.; ZHAO, J.J.; XU, J.; FENG, F.; QU, W. Medicinal uses, phytochemistry and pharmacology of the genus Uncaria. J. Ethnopharmacol., v.173, p.48-80, 2015.

Received for publication on $19^{\text {th }}$ February 2016 Accepted for publication on $04^{\text {th }}$ November 2016 